Article

\title{
Removal of Copper, Nickel, and Zinc Ions from an Aqueous Solution through Electrochemical and Nanofiltration Membrane Processes
}

\author{
Jagdeesh Kumar ${ }^{1, *}$, Himanshu Joshi ${ }^{1}$ and Sandeep K. Malyan ${ }^{2, *(D)}$ \\ 1 Department of Hydrology, Indian Institute of Technology Roorkee, Roorkee 247667, India; \\ himanshu.joshi@hy.iitr.ac.in \\ 2 Research Management and Outreach Division, National Institute of Hydrology, Jalvigyan Bhawan, \\ Roorkee 247667, India \\ * Correspondence: jkumar@hy.iitr.ac.in (J.K.); sandeepkmalyan@gmail.com (S.K.M.)
}

Citation: Kumar, J.; Joshi, H.; Malyan, S.K. Removal of Copper, Nickel, and Zinc Ions from an Aqueous Solution through Electrochemical and Nanofiltration Membrane Processes. Appl. Sci. 2022, 12, 280. https:// doi.org/10.3390/app12010280

Academic Editor: Bart Van der Bruggen

Received: 15 October 2021

Accepted: 22 December 2021

Published: 28 December 2021

Publisher's Note: MDPI stays neutral with regard to jurisdictional claims in published maps and institutional affiliations.

Copyright: (C) 2021 by the authors. Licensee MDPI, Basel, Switzerland. This article is an open access article distributed under the terms and conditions of the Creative Commons Attribution (CC BY) license (https:// creativecommons.org/licenses/by/ $4.0 /)$.

\begin{abstract}
Heavy metal contamination in water is a major health concern, directly related to rapid growth in industrialization, urbanization, and modernization in agriculture. Keeping this in view, the present study has attempted to develop models for the process optimization of nanofiltration (NF) membrane and electrocoagulation (EC) processes for the removal of copper, nickel, and zinc from an aqueous solution, employing the response surface methodology (RSM). The variable factors were feed concentration, temperature, $\mathrm{pH}$, and pressure for the NF membrane process; and time, solution $\mathrm{pH}$, feed concentration, and current for the EC process, respectively. The central composite design (CCD), the most commonly used fractional factorial design, was employed to plan the experiments. RSM models were statistically analyzed using analysis of variance (ANOVA). For the NF membrane, the rejection of $\mathrm{Zn}, \mathrm{Ni}$, and $\mathrm{Cu}$ was observed as $98.64 \%, 90.54 \%$, and $99.79 \%$ respectively; while the removal of these through the EC process was observed as $99.81 \%, 99.99 \%$, and $99.98 \%$, respectively. The above findings and a comparison with the conventional precipitation and adsorption processes apparently indicate an advantage in employing the NF and EC processes. Further, between the two, the EC process emerged as more efficient than the NF process for the removal of the studied metals.
\end{abstract}

Keywords: nanofiltration; electrocoagulation; nickel; zinc; copper; heavy metals; water pollution

\section{Introduction}

Heavy metals are inorganic elements naturally found throughout the earth's crust [1] Their concentration above permissible limits is considered pollution. "Heavy metals" refers to a group of elements with a density greater than $4 \mathrm{~g} \mathrm{~cm}^{-3}$, including metals and metalloids [2]. Industrial discharges, agricultural runoff, storm water, mining activity, and direct inclusion of sewage/wastewater contribute to the heavy metal pollution load in fresh water, leading to various health and environmental problems. Among the commonly reported heavy metals, copper $(\mathrm{Cu})$ is used widely in electroplating, batteries, pesticides, galvanized pipes, and alloys [3-7]. Regular consumption of copper-contaminated drinking water may cause stomach upsets, abdominal cramp and diarrhea. Nickel (Ni) is another metal found widely in water and wastewater. The electroplating industry, rechargeable batteries, and galvanized pipes are its main sources. High levels of nickel contamination cause serious lung and kidney problems as well as skin dermatitis and pulmonary fibrosis. In drinking water, the maximum allowable limit for nickel is $0.1 \mathrm{ppm} \mathrm{[8].} \mathrm{Zinc} \mathrm{(Zn)} \mathrm{is} \mathrm{used}$ in many types of industry, such as metal production, galvanization, food preservation, agri-food and biological engineering, pharmaceuticals, electronics, mining and metallurgy, with major contributions coming from electroplating and mining effluents [9,10]. Zinc is not considered highly toxic but its presence in drinking water if exceeding $15 \mathrm{mg} / \mathrm{L}$ is reported to cause nausea, vomiting and diarrhea [11]. These heavy metals are ingested directly either 
by drinking contaminated water or indirectly through the food chain, and subsequently affect human health [12-14]. Drinking of contaminated water has been reported to lead to around $70-80 \%$ of the total diseases in developing countries $[15,16]$, where the impact of increased pollution is particularly problematic because the population at large does not have sufficient resources to effectively treat the contaminated water or access to safe drinking water systems at their homes. According to a WHO (2017) estimate, around 844 million people do not have access to a basic drinking water source and 230 million people spend more than $30 \mathrm{~min} /$ day in collecting water from an improved water source, which may include piped water, boreholes, protected wells and springs, rainwater and packaged/delivered water [17]. According to the United Nations, an estimated $80 \%$ of all industrial and municipal wastewater in the developing world is released into freshwater bodies without any prior treatment [18]. Heavy metal removal can be achieved through different physical, chemical and biological methods such as fungal remediation [19], microbial remediation [12,20], phytoremediation [21,22], adsorption [23,24], flotation, coagulationflocculation [25], chemical precipitation or ion exchange [26]; selection between these may be based on the nature and quantum of the pollution load and merits/demerits of decontamination processes along with other factors. It is noted that removal of heavy metals from water/wastewater is still an evolving research area, and there is wide scope for case-specific evaluation, optimization and integration of new and/or available technologies. In this regard, it has been noted that removal of heavy metals from aqueous solutions, especially metal-laden water or wastewater displaying high and heterogeneous concentrations is one of the major challenges. For this, nanofiltration (NF) and electrocoagulation (EC) processes have been reportedly more reliable than bioremediation in terms of the shorter time taken in providing near complete removal, ease of setup, and predictability. The primary emphasis of the present study is to explore the efficiency of removal of $\mathrm{Cu}, \mathrm{Ni}$, and $\mathrm{Zn}$ by NF and EC processes from their synthetic aqueous solutions in low to high concentrations. The selection of these metals for study is based on the findings of a comprehensive literature review, indicating that these comprise the major constituents in electroplating effluents or the recipient waters of these effluents.

\section{Materials and Methods}

\subsection{Chemicals, Membranes and Electrodes}

The experiments were conducted for the technical evaluation of the NF and EC processes employing a range of concentrations of metals in aqueous solution based on the available secondary data on electroplating effluent quality in the literature and also in the study area $[27,28]$. All chemicals used in this research were of analytical grade, and synthetic composite metal solutions were prepared by dissolving the appropriate mass of each metal in high purity Milli-Q water $(18.2 \mathrm{M} \Omega \mathrm{cm}$ ). Copper (III) sulphate pentahydrate $\mathrm{CuSO}_{4} \cdot 5 \mathrm{H}_{2} \mathrm{O}$, nickel (II) sulphate hexahydrate $\mathrm{NiSO}_{4} \cdot 6 \mathrm{H}_{2} \mathrm{O}$, zinc sulphate $\mathrm{ZnSO}_{4} \cdot 7 \mathrm{H}_{2} \mathrm{O}$, sodium hydroxide $(\mathrm{NaOH})$, nitric acid $(69-72 \%)$, sodium chloride $(\mathrm{NaCl})$ and calcium carbonate extra pure $\left(\mathrm{CaCO}_{3}\right)$ were all obtained from Merck Specialties Private Ltd. Quicklime (CaO), nanofiltration membrane (Permionics, Flat Sheet Membrane HFN-300 AR) and stainless steel (SS-304) electrodes were procured from the market as commercially available. The stated membrane was specifically employed so as to effectively work in both acid and basic medium. Stainless steel electrodes were used, as they are less susceptible to corrosion, and have reportedly shown a better performance in earlier studies. The grade of steel used is reported to not contain $\mathrm{Zn}$, and have very low amount of carbon.

\subsection{Experimental Setup and Procedure}

\subsubsection{Experimental Setup for Nanofiltration}

The NF unit was a cross-flow lab-scale system (Nilshan Nishotech Pvt. Ltd., Navi Mumbai, India). It consisted of a high-pressure pump, feed vessel, flat membrane sheet housing cell, and a temperature control unit (Figure 1a). The membrane housing cell contained a rectangular channel. The active surface area of the membrane was $0.0155 \mathrm{~m}^{2}$. Lab experiments were 
conducted by filtering the multicomponent solution with NF membrane. The permeate and the concentrate streams were recirculated back into the feed tank continuously during experiments. After the completion of every single experiment, the system was appropriately cleaned by Milli-Q water. The samples were collected after each experiment.

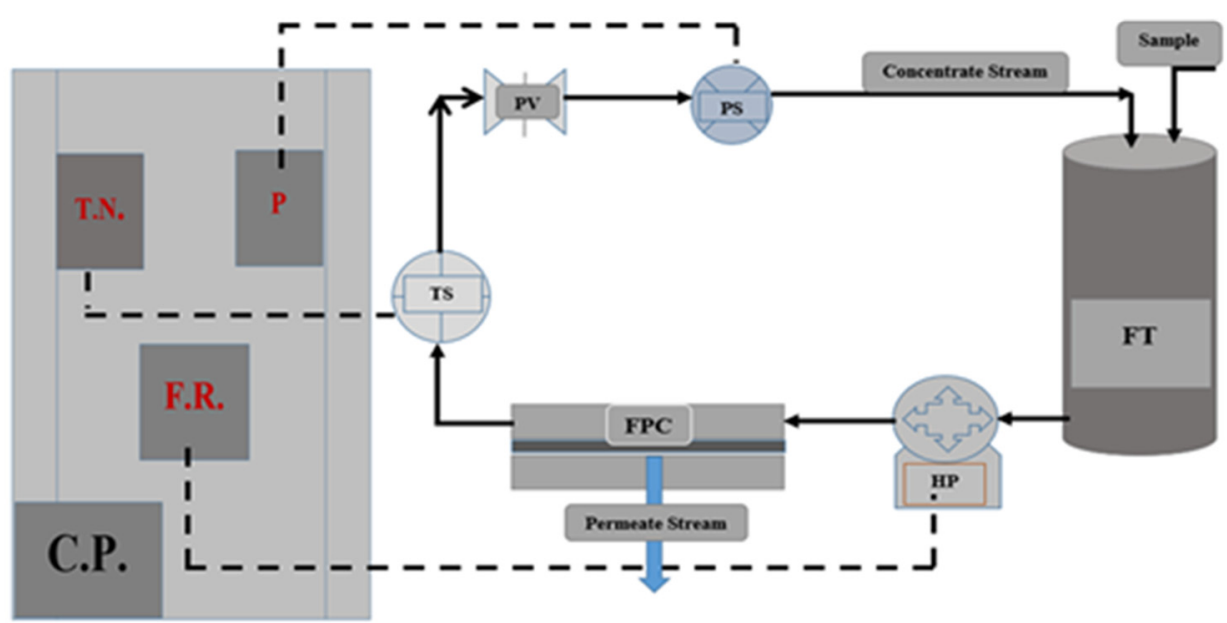

(a)

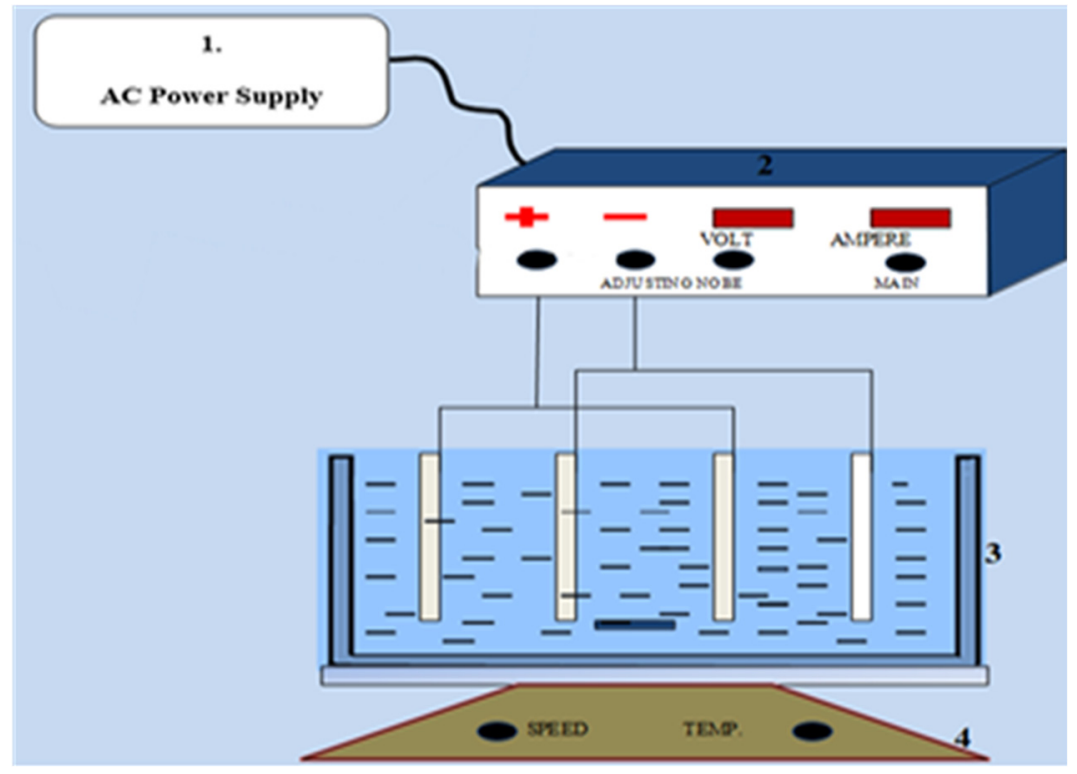

(b)

Figure 1. (a) Flat Plate Membrane System. (Control Panel, $T N=$ Temperature Node, $P=$ Pressure Node, FR = Flow Rate Controller node, TS = Temperature Sensor, PV = Pressure Valve, PS = Pressure Sensor, FPC = Flat Plate Membrane Cell, HP = High-Pressure Pump, FT = Feed Tank.). (b) Laboratory scale experimental setup of electrocoagulation unit. (1-AC, power scheme; 2 , direct current supply; 3 , treatment vessel, consists of anode and cathode in mono-polar mode, magnetic-bead; 4, magnetic stirrer).

\subsubsection{Experimental Set for Electrocoagulation}

The electrocoagulation (EC) experimental setup consisted of a DC power supply unit for constant DC output. The experimental reactor $(11.0 \mathrm{~cm} \times 11.0 \mathrm{~cm} \times 15.0 \mathrm{~cm})$ was made of plexiglass and four mono-polar stainless-steel plates $(9.0 \mathrm{~cm} \times 9.0 \mathrm{~cm} \times 0.1 \mathrm{~cm})$ submerged in the solution as the electrodes (Figure $1 \mathrm{~b}$ ). Plate spacing was $1 \mathrm{~cm}$. The magnetic stirrer was used to provide proper stirring to maintain the uniformity of the solution throughout the reactor. Initially, at the start of each EC experimental run, 1.8 L of the synthetic solution 
was put into the electrolytic reaction cell after mixing it with one gm/L electrolyte $(\mathrm{NaCl})$. The $\mathrm{pH}$ of the solution was measured and maintained by adding drops of $0.1 \mathrm{~N} \mathrm{NaOH}$ and $\mathrm{H}_{2} \mathrm{SO}_{4}$ solution using a $\mathrm{pH}$ meter. The current was controlled through the power supply regulator. Samples were collected at the end of the electrolysis process.

Samples collected after the experiments employing different treatment processes were digested through the microwave digestion unit (Anton Par) and filtered by $0.42 \mu$ filter papers. They were further analyzed by inductively coupled plasma mass spectroscopy (ICP-MS of Agilent). The removal efficiency was determined by calculating the difference in the concentrations measured by ICP-MS before and after each experiment.

\subsection{Preparation of Working Solutions}

Metal solutions were prepared by dissolving the appropriate mass of each metal in high purity Milli-Q water $(18.2 \mathrm{M} \Omega \mathrm{cm})$, as mentioned earlier. All metal salts were added sequentially, after the previous metal salt had completely dissolved. Thereafter, the mixed-metal solutions with different concentrations ( $\mathrm{ppm}$ ) were prepared for each batch experiment.

\subsection{Calculation of Removal Percentage}

The removal efficiency of any metal can be calculated using the following equation:

$$
\mathrm{R}(\%)=\frac{\mathrm{C}_{\mathrm{i}-\mathrm{C}_{\mathrm{f}}}}{\mathrm{C}_{\mathrm{i}}} \times 100
$$

where $C_{i}$ and $C_{f}(m g / L)$ denote the concentration of the metal before and after the treatment process, respectively.

\subsection{Experimental Design and Optimization through Response Surface Methodology}

For mathematical modelling of the process, an empirical approach [29-31] employing response surface methodology (RSM) was adopted [32-34]. RSM reportedly reduces systematic errors with an estimation of investigational error and also reduces the number of experiments [30], requires lesser computer simulations, is more accessible and more efficient than the other methods based on limited components or computational complexity [31].

RSM based on the central composite design (CCD) was used to examine the efficacy of the NF membrane and EC processes. CCD helped in arriving at the operational conditions highlighting the highest removal efficiency scenarios. In the NF membrane process, the solution $\mathrm{pH}$, pressure, concentration, and temperature were the key factors widely reported to contribute to the removal of metal ions [35-38] and thus design expert software was used for the experimental design with a varying range of these factors (Table 1).

Table 1. Factor and range for design experiments of NF membrane and EC.

\begin{tabular}{|c|c|c|c|c|c|c|}
\hline \multirow{2}{*}{ Code } & \multirow{2}{*}{ Factors } & \multicolumn{5}{|c|}{ Coded Level of N.F. } \\
\hline & & $-\alpha$ & -1 & 0 & +1 & $+\alpha$ \\
\hline $\mathrm{X}_{1}$ & $\mathrm{pH}$ & 2.0 & 4.5 & 7.0 & 9.5 & 12.0 \\
\hline$X_{2}$ & Pressure (bar) & 2.5 & 10 & 17.5 & 25 & 32.5 \\
\hline$X_{3}$ & Concentration (ppm) & 2.5 & 10 & 17.5 & 25 & 32.5 \\
\hline$X_{4}$ & Temperature $\left({ }^{\circ} \mathrm{C}\right)$ & 5 & 15 & 25 & 35 & 45 \\
\hline \multirow{2}{*}{ Code } & \multirow{2}{*}{ Factors } & \multicolumn{5}{|c|}{ Coded level of E.C. } \\
\hline & & $-\alpha$ & -1 & 0 & +1 & $+\alpha$ \\
\hline $\mathrm{X}_{1}$ & $\mathrm{pH}$ & 3.0 & 4.5 & 6.0 & 7.5 & 9.0 \\
\hline$X_{2}$ & Time (min) & 20 & 40 & 60 & 80 & 100 \\
\hline$X_{3}$ & Concentration(ppm) & 2.5 & 10 & 17.5 & 25 & 32.5 \\
\hline$X_{4}$ & Current $(\AA)$ & 0.5 & 1.0 & 1.5 & 2.0 & 2.5 \\
\hline
\end{tabular}


In the EC process, solution $\mathrm{pH}$, time, concentration, and current were the key factors [25] widely reported to contribute to the removal of metal ions [39-42] and thus design expert software was used for experimental design with a varying range of these factors (Table 1). The initial and final conductivity values were 2.78 and $2.35 \mathrm{mS} / \mathrm{cm}$ for the final optimum condition. The complete design matrix of the NF membrane and EC processes obtained after the application of CCD is presented in Supplementary Table S1 and Supplementary Table S2 respectively, which suggest thirty sets of runs and six centrally coded level runs for each treatment process.

\section{Results and Discussion}

In this study, experiments were performed for different combinations of factors for both processes, as described in the following sections.

\subsection{Experimental Performance of NF}

The details of the coded variables $\left(X_{1}, X_{2}, X_{3}\right.$ and $\left.X_{4}\right)$, and their response values are presented in supplementary (Supplementary Table S1).

\subsubsection{Statistical Analysis and Modelling by RSM}

The NF membrane process responses were studied for the permeate flux and metal rejections $(\mathrm{Zn}, \mathrm{Cu}$, and $\mathrm{Ni})$. The findings of the experimental studies were analyzed statistically through analysis of variance (ANOVA). Table 2 shows the ANOVA models.

Table 2. ANOVA analysis for the NF membrane.

\begin{tabular}{|c|c|c|c|c|c|c|c|c|}
\hline Source & Sum of Squares & Degree of Freedom & Mean Square & F-Value & $p$-Value & $R^{2}$ & $R_{\text {adj }}^{2}$ & Responses \\
\hline Model & 5816.87 & 14 & 415.49 & 70.29 & $<0.0001$ & 0.985 & 0.971 & Flux \\
\hline Model & $17,449.52$ & 14 & 1246.39 & 12.41 & $<0.0001$ & 0.9205 & 0.8464 & Zn Removal\% \\
\hline Model & $10,360.61$ & 14 & 740.04 & 5.07 & 0.0017 & 0.8255 & 0.6626 & Ni Removal\% \\
\hline Model & 2541.01 & 14 & 181.50 & 19.12 & $<0.0001$ & 0.9469 & 0.8974 & Cu Removal\% \\
\hline
\end{tabular}

For the above models, Fisher's test statistic ( $F$-Value) clarifies the scattering of actual data around the fitted models, while the $p$-value indicates the significance of the model terms. The $\mathrm{F}$ value of responses suggested that the respective models were significant regarding the residual error. The $p$-value of a model lower than 0.05 indicates a significant model, and higher than 0.10 means an insignificant model. The $p$-value of all responses were lower than 0.0001 , suggesting that the models are highly significant. The coefficient of regression $\left(R^{2}\right)$ described the system behaviour and the adequacy of the model in the range of independent variables. The high $R^{2}$ and adjusted $R^{2}$ in Table 2 also reveal that the models are highly significant.

The quadratic regression model equations for NF membrane permeate flux $\left(\mathrm{Y}_{1}\right)$, $\mathrm{Zn}$ removal $\left(\mathrm{Y}_{2}\right)$, Ni removal $\left(\mathrm{Y}_{3}\right)$, and $\mathrm{Cu}$ removal $\left(\mathrm{Y}_{4}\right)$ in terms of coded factors are presented below as Equations (2)-(5), respectively.

$$
\begin{aligned}
& \mathrm{Y}_{1}=+26.75+1.84 \mathrm{X}_{1}+12.96 \mathrm{X}_{2}+0.51 \mathrm{X}_{3}+7.08 \mathrm{X}_{4}-1.06 \mathrm{X}_{1}^{2}+0.51 \mathrm{X}_{2}^{2}+1.36 \mathrm{X}_{3}^{2}+3.04 \mathrm{X}_{4}^{2} \\
& +1.06 \mathrm{X}_{1} \mathrm{X}_{2}-0.53 \mathrm{X}_{1} \mathrm{X}_{3}+0.82 \mathrm{X}_{1} \mathrm{X}_{4}+0.33 \mathrm{X}_{2} \mathrm{X}_{3}+2.5 \mathrm{X}_{2} \mathrm{X}_{4}+0.77 \mathrm{X}_{3} \mathrm{X}_{4} \\
& \mathrm{Y}_{2}=+89.32+24.78 \mathrm{X}_{1}-1.62 \mathrm{X}_{2}-4.67 \mathrm{X}_{3}-2.82 \mathrm{X}_{4}-6.26 \mathrm{X}_{1}^{2}-4.22 \mathrm{X}_{2}^{2}-4.71 \mathrm{X}_{3}^{2}-3.91 \mathrm{X}_{4}^{2} \\
& +0.52 \mathrm{X}_{1} \mathrm{X}_{2}+1.96 \mathrm{X}_{1} \mathrm{X}_{3}+0.67 \mathrm{X}_{1} \mathrm{X}_{4}-0.34 \mathrm{X}_{2} \mathrm{X}_{3}-1.25 \mathrm{X}_{2} \mathrm{X}_{4}+0.23 \mathrm{X}_{3} \mathrm{X}_{4} \\
& \mathrm{Y}_{3}=+84.38+19.27 \mathrm{X}_{1}-2.23 \mathrm{X}_{2}-3.82 \mathrm{X}_{3}-2.17 \mathrm{X}_{4}-0.43 \mathrm{X}_{1}^{2}-3.58 \mathrm{X}_{2}^{2}-3.46 \mathrm{X}_{3}^{2}-3.75 \mathrm{X}_{4}^{2} \\
& +0.61 \mathrm{X}_{1} \mathrm{X}_{2}+0.59 \mathrm{X}_{1} \mathrm{X}_{3}+0.31 \mathrm{X}_{1} \mathrm{X}_{4}-0.52 \mathrm{X}_{2} \mathrm{X}_{3}+0.076 \mathrm{X}_{2} \mathrm{X}_{4}+0.26 \mathrm{X}_{3} \mathrm{X}_{4} \\
& \mathrm{Y}_{4}=+92.65+8.88 \mathrm{X}_{1}-0.85 \mathrm{X}_{2}-2.02 \mathrm{X}_{3}-1.04 \mathrm{X}_{4}-3.76 \mathrm{X}_{1}^{2}+0.66 \mathrm{X}_{2}^{2}+0.47 \mathrm{X}_{3}^{2}-0.46 \mathrm{X}_{4}^{2} \\
& +0.44 \mathrm{X}_{1} \mathrm{X}_{2}+1.50 \mathrm{X}_{1} \mathrm{X}_{3}+0.31 \mathrm{X}_{1} \mathrm{X}_{4}-0.33 \mathrm{X}_{2} \mathrm{X}_{3}+0.070 \mathrm{X}_{2} \mathrm{X}_{4}+0.27 \mathrm{X}_{3} \mathrm{X}_{4}
\end{aligned}
$$




\subsubsection{Response Surface Plots}

The response surface plot for the permeate flux of NF is presented in Figure 2. The observations show an upsurge in the permeate flux simultaneously with the increase in trans-membrane pressure. It has been well established that permeate flux depends on pressure and gets amplified almost linearly with increasing pressure [32-36]. The maximum permeate flux of $59.34 \mathrm{~L} / \mathrm{m}^{2} \cdot \mathrm{h}$ is obtained at the feed concentration of $25 \mathrm{ppm}, \mathrm{pH} 9.5$, pressure 25 bar, and temperature $35^{\circ} \mathrm{C}$, as shown in Figure 2. It is typically theorized that an increased temperature accelerates the permeate flux due to one or more reasons such as a decline in solvent viscosity, a rise in solvent diffusion, intensification in the solvent diffusion coefficient, or a surge in polymer chain mobility [24]. Membrane-solvent interactions can be expected to differ with a change in solvent properties, like dielectric constant, molecular size, dipole movements, and Hildebrand solubility parameter. The rise in temperature also affects structural properties such as pore radius and membrane thickness, which have shown a much more noticeable impact on membrane performance in comparison to solvent and solute motilities [37-39]. Experiments have demonstrated a linear increase in the slope of flux with a rise in temperature, as reported by others $[40,41]$. Figure 2a shows a direct increase of permeate flux with an increase in trans-membrane pressure. Figure $2 b$ demonstrates a significant increase in the permeate flux with an increase in temperature. Water permeation by micropores is an activated process that is absolutely dissimilar from viscous flow. It should be taken into account that the water molecule is one of the smallest molecules, having the same range of kinetic diameter $(0.29 \mathrm{~nm})$, as helium $(0.24 \mathrm{~nm})$ and hydrogen $(0.27 \mathrm{~nm})$. A portion of water molecules gets adequate thermal energy to cross the energy barrier from the pore wall and passes over the pores, which is another justification based on the adsorption of water on hydrophilic pore walls. The actual pore diameter might get reduced by the water adsorbed on pore walls. In such a case, the adsorbed water layer can be thinner at higher temperatures resulting in the effective pore diameter becoming more extensive [41].

The separation of metal ions by NF is attained by size exclusion, and electrical interactions between the ions in the feed aqueous solution and the charged NF membranes. The degree of ionization of these functional groups is a function of the solution $\mathrm{pH}$, which influences the membrane charge and, therefore, the rejection properties of the membrane [41]. The rejection of $\mathrm{Cu}, \mathrm{Ni}$, and $\mathrm{Zn}$ ions increased with the increase in the solution $\mathrm{pH}$ $($ Figure $3 \mathrm{a}-\mathrm{c})$. The feed solution $\mathrm{pH}$ determines the ion charge in the solution and the surface charge density of the membranes. The more the $\mathrm{pH}$ increases, the more the membrane charge becomes positive, leading to a stronger electrostatic repulsion between the membrane and the metal ions [35]. Copper hydroxide precipitation starts at $\mathrm{pH}$ 5.24, and the precipitation of the other metals $(\mathrm{Zn}$ and $\mathrm{Ni}$ ) at a still higher $\mathrm{pH}$. At the different $\mathrm{pH}$ values studied, the rejection of copper was higher than for $\mathrm{Zn}$ and $\mathrm{Ni}$ ions, as reported earlier [42]. The maximum rejection of $\mathrm{Cu}, \mathrm{Zn}$, and $\mathrm{Ni}$ was demonstrated as $99.99 \%$, $99.96 \%$ and $99.63 \%$, respectively, in the experiments where concentrations ranged between 10-25 ppm and pressure between 10-25 bar. It was observed that the rejection of metal ions decreased when the concentration of feed solution increased, a common phenomenon for NF membranes [37]. The increase in concentration in the feed solution apparently generates a screen formation of cation adjacent to the membrane on the high-pressure side, which neutralizes the negative charges of the NF membrane. Thus, the total negative charge of the membrane decreases, and the repulsion between membrane and anion decreases. As a result, the co-ions (ions with the same charge as the membrane) quickly escape through the membrane and due to electro-neutrality, the rejection of counter-ions is reduced $[8,43]$. Figure $3 \mathrm{~d}-\mathrm{f}$ shows a slight decrease in the rejection of $\mathrm{Ni}$ and $\mathrm{Zn}$ ions with an increase in feed solution concentration, whereas the rejection of the $\mathrm{Cu}$ ions was not much affected. Temperature and pressure also have not shown much influence upon the rejection of the metal ions. Overall, the findings of this study are quite in line with some other relevant studies, as displayed in Table 3. 


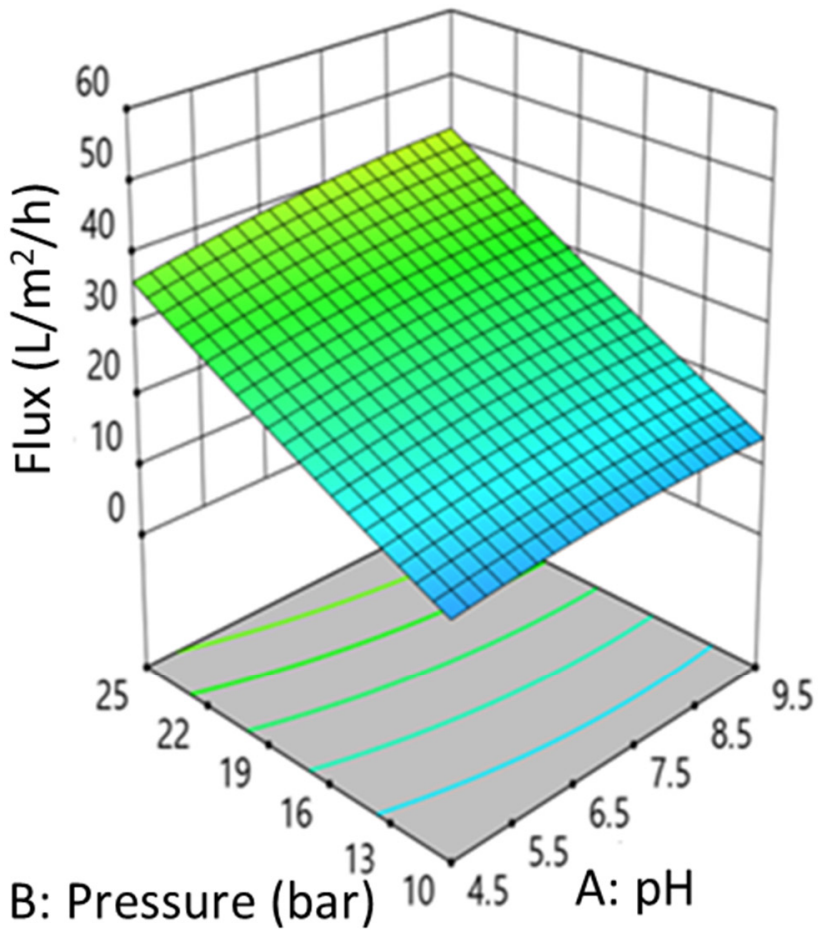

(a)

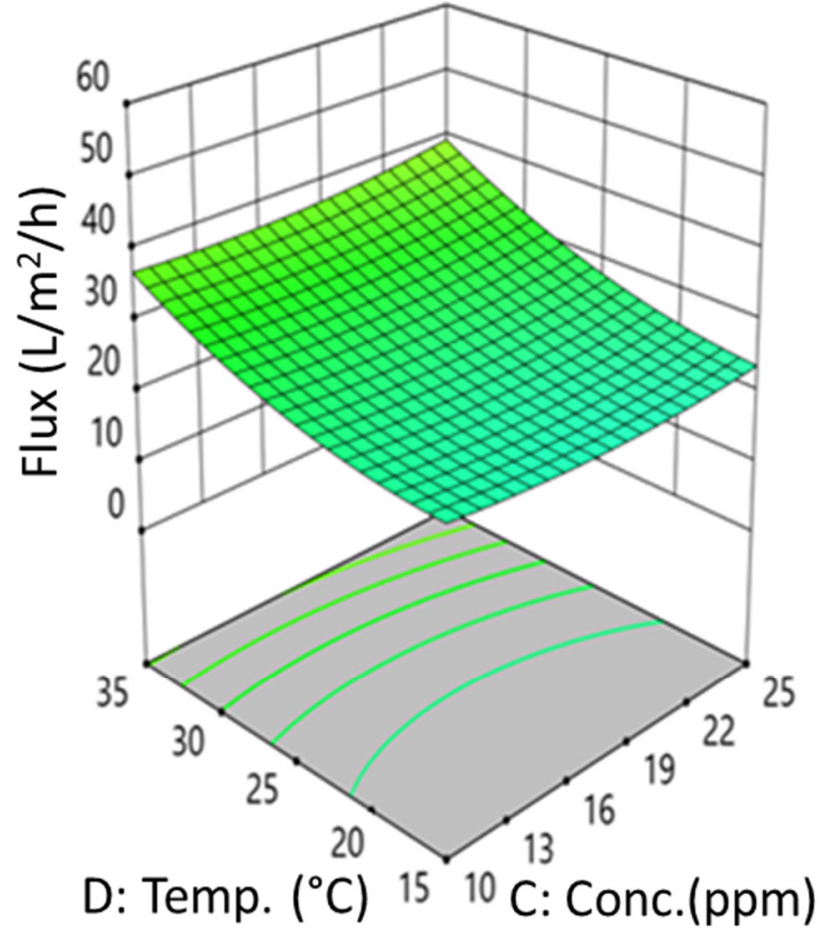

(b)

Figure 2. RSM plot for permeate flux. (a) Effect of pressure and pH. (b) Effect of temperature and concentration.

Table 3. Comparison of rejection efficiency of metals ions by NF membrane between this and other studies in the literature.

\begin{tabular}{|c|c|c|c|}
\hline Pollutants/Wastewater Type & Membrane & Metal Rejection/Removal & References \\
\hline Synthetic metal ion solution & NF & Zn (98.64\%), Ni (90.54\%), and Cu (99.79\%) & Current study \\
\hline Synthetic metal ion solution & NF & $\begin{array}{c}\mathrm{Zn}(96.7 \%), \mathrm{Mg}(95.01 \%), \mathrm{Cd}(92.4 \%), \mathrm{Cu}(91.9 \%), \mathrm{Ca} \\
(91.3 \%), \mathrm{Ni}(90.7 \%), \text { and } \mathrm{Pb}(90.5 \%)\end{array}$ & {$[44]$} \\
\hline Synthetic metal ion solution & $\mathrm{NF}$ and $\mathrm{FO}$ & $\begin{array}{l}\text { Cu-(II) } 95 \% \text { and } 99 \% \text { in NF } \\
\text { and F.O., respectively. }\end{array}$ & [45] \\
\hline Synthetic metal ion solution & NF & $\mathrm{Cu}$ ion rejection was $>90 \%$ & [46] \\
\hline Synthetic metal ion solution & $\mathrm{NF}$ & $\mathrm{Cu}(99.82 \%), \mathrm{As}(\mathrm{V})(96.75 \%)$, and $\mathrm{Cr}(97.22 \%)$ & [47] \\
\hline Electroplating wastewater & NF & $\mathrm{Ni}(88.093 \%)$ and $\mathrm{Cr}(80.271 \%)$ & [48] \\
\hline Synthetic metal ion solution & NF & $\mathrm{Ni}(93 \%)$ & [8] \\
\hline Synthetic metal ion solution & NF & $\mathrm{Cu}(100 \%), \mathrm{Cd}(99 \%), \mathrm{Mn}(89 \%)$, and $\mathrm{Pb}(74 \%)$ & [37] \\
\hline Synthetic metal ion solution & NF & $\mathrm{Cd}(97.26 \%)$ and $\mathrm{Ni}(98.90 \%)$ & [49] \\
\hline Synthetic metal ion solution & NF & $\mathrm{Ni}(98.94 \%)$ and $\mathrm{Cd}(82.69 \%)$ & [50] \\
\hline
\end{tabular}




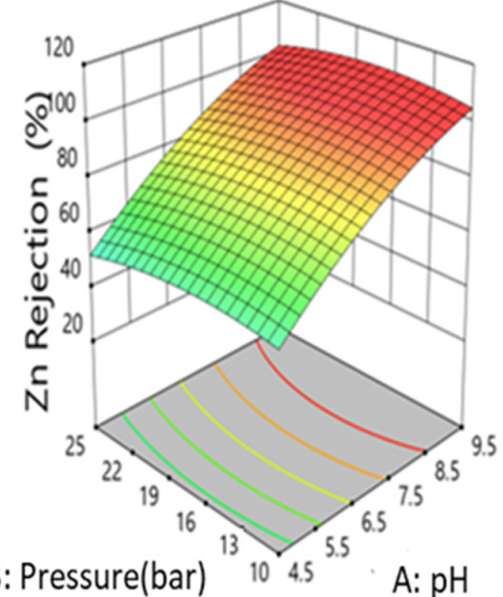

(a)

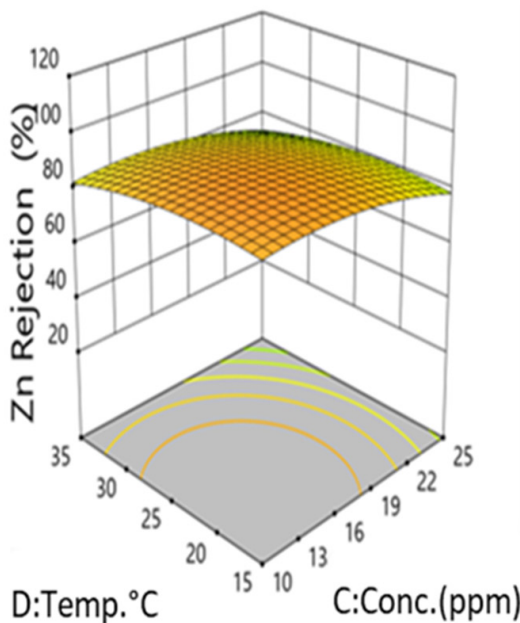

(d)

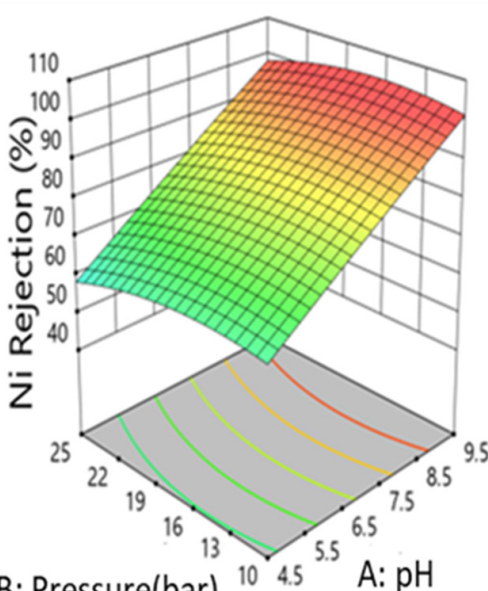

(b)

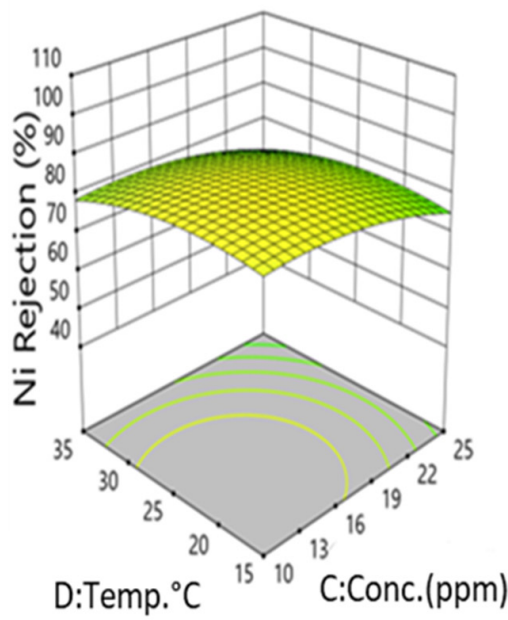

(e)

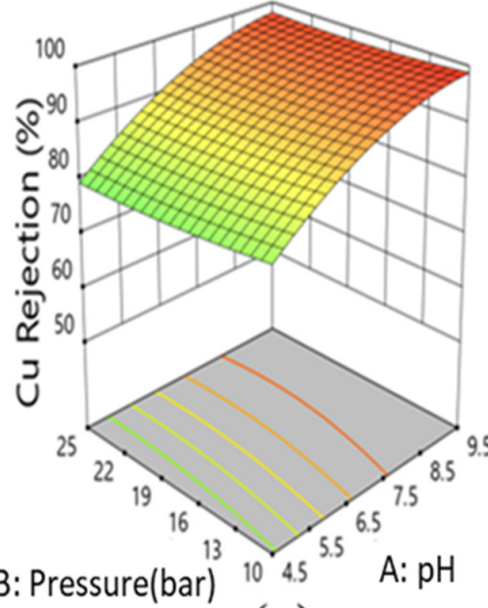

(c)

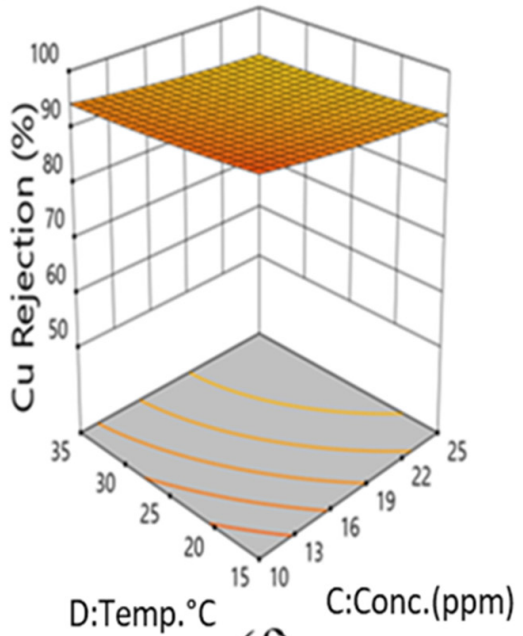

(f)

Figure 3. NF membrane RSM plots for $\mathrm{pH}$ and pressure effects on metals ions rejection \% efficiency(a) Zn ions, (b) Ni ions, and (c) Cu ions; and effect of temperature and concentration on metal ions rejection \% efficiency-(d) Zn ions, (e) $\mathrm{Ni}$ ions, and (f) $\mathrm{Cu}$ ions.

\subsubsection{Multi Response Optimization}

The optimization of all input variables was done using the desirability function approach to arrive at the best response values of the factors $Y_{1}, Y_{2}, Y_{3}, Y_{4}$. As depicted in Table 4, at the optimal condition, the predicted response values of factors $\left(\mathrm{Y}_{1}, \mathrm{Y}_{2}, \mathrm{Y}_{3}, \mathrm{Y}_{4}\right)$ were observed as $36.9\left(\mathrm{~L} / \mathrm{m}^{2} \cdot \mathrm{h}\right), 94.77 \%, 88.67 \%, 95.89 \%$, respectively. The average values of factor responses after three runs, were found to be $41.93\left(\mathrm{~L} / \mathrm{m}^{2} \cdot \mathrm{h}\right)$ for $\mathrm{Y}_{1}, 98.64 \%$ for $\mathrm{Y}_{2}$, $90.54 \%$ for $Y_{3}$, and $99.79 \%$ for $Y_{4}$. All the experimentally derived values are close to the predicted response values, showing a good correlation (Table 4).

Table 4. NF Optimization of response through RSM.

\begin{tabular}{cccccc}
\hline Optimum Input Variables (Feed Solution) & \multicolumn{2}{c}{ Predicted Responses by RSM } & Experimental Validation & Difference $\%$ \\
\hline Concentration $(\mathrm{ppm})$ & 14.24 & Flux $\left(\mathrm{L} / \mathrm{m}^{2} \cdot \mathrm{h}\right)$ & 36.92 & 41.93 & 13.58 \\
\hline Temperature $\left({ }^{\circ} \mathrm{C}\right)$ & 25 & Zn Removal\% & 94.77 & 98.64 & 4.08 \\
\hline $\mathrm{pH}$ & 7.84 & Ni Removal\% & 88.67 & 90.54 & 2.11 \\
\hline Pressure (Bar) & 22.79 & Cu Removal\% & 95.89 & 99.79 & 4.07 \\
\hline
\end{tabular}




\subsection{Experimental Performance of EC}

The details of the coded variables $\left(\mathrm{X}_{1}, \mathrm{X}_{2}, \mathrm{X}_{3}\right.$ and $\left.\mathrm{X}_{4}\right)$, and their response values are presented in Supplementary Table S2.

\subsubsection{Statistical Analysis and Modelling by RSM}

The findings of the experimental studies were analyzed statistically through analysis of variance (ANOVA). Table 5 shows the ANOVA models.

Table 5. ANOVA analysis for the EC process.

\begin{tabular}{ccccccccc}
\hline Source & Sum of Squares & Degree of Freedom & Mean Square & $\boldsymbol{F}$-Value & $\boldsymbol{p}$-Value & $\boldsymbol{R}^{\mathbf{2}}$ & $\boldsymbol{R}^{\mathbf{2}}$ adj & Responses \\
\hline Model & $10,750.36$ & 14 & 767.88 & 6.03 & 0.0007 & 0.8492 & 0.7085 & Zn Removal\% \\
\hline Model & $13,024.85$ & 14 & 930.35 & 9.39 & $<0.0001$ & 0.8976 & 0.8020 & Ni Removal\% \\
\hline Model & 940.48 & 14 & 67.18 & 2.78 & 0.0293 & 0.7220 & 0.4625 & Cu Removal\% \\
\hline
\end{tabular}

The $F$ and $p$ values presented in Table 5 indicate that the fitted models are significant. The values of $R^{2}$ and adjusted $R^{2}$ in the Table 5 also reveal the high significance levels of the models.

The quadratic regression model Equations (6)-(8) for $\mathrm{Zn}$ removal $\left(\mathrm{Y}_{1}\right)$, Ni removal $\left(\mathrm{Y}_{2}\right)$ and $\mathrm{Cu}$ removal $\left(\mathrm{Y}_{3}\right)$ in terms of coded factors are given below.

$$
\begin{aligned}
& \mathrm{Y}_{1}=+93.51+7.05 \mathrm{X}_{1}+10.35 \mathrm{X}_{2}-5.22 \mathrm{X}_{3}+10.69 \mathrm{X}_{4}-0.030 \mathrm{X}_{1}^{2}-7.46 \mathrm{X}_{2}^{2}+0.58 \mathrm{X}_{3}^{2}-6.74 \mathrm{X}_{4}^{2} \\
& +0.039 \mathrm{X}_{1} \mathrm{X}_{2}+4.07 \mathrm{X}_{1} \mathrm{X}_{3}-4.70 \mathrm{X}_{1} \mathrm{X}_{4}+0.81 \mathrm{X}_{2} \mathrm{X}_{3}-0.60 \mathrm{X}_{2} \mathrm{X}_{4}+4.38 \mathrm{X}_{3} \mathrm{X}_{4} \\
& \mathrm{Y}_{2}=+90.88+9.06 \mathrm{X}_{1}+12.42 \mathrm{X}_{2}-5.53 \mathrm{X}_{3}+10.75 \mathrm{X}_{4}-2.14 \mathrm{X}_{1}^{2}-8.60 \mathrm{X}_{2}^{2}+0.069 \mathrm{X}_{3}^{2}-7.71 \mathrm{X}_{4}^{2} \\
& -1.75 \mathrm{X}_{1} \mathrm{X}_{2}+1.35 \mathrm{X}_{1} \mathrm{X}_{3}-4.46 \mathrm{X}_{1} \mathrm{X}_{4}+1.01 \mathrm{X}_{2} \mathrm{X}_{3}+0.93 \mathrm{X}_{2} \mathrm{X}_{4}+2.24 \mathrm{X}_{3} \mathrm{X}_{4} \\
& \mathrm{Y}_{3}=+97.05+2.00 \mathrm{X}_{1}+3.69 \mathrm{X}_{2}-1.00 \mathrm{X}_{3}+3.06 \mathrm{X}_{4}+0.10 \mathrm{X}_{1}^{2}-2.19 \mathrm{X}_{2}^{2}+0.79 \mathrm{X}_{3}^{2}-1.55 \mathrm{X}_{4}^{2} \\
& +0.081 \mathrm{X}_{1} \mathrm{X}_{2}-0.57 \mathrm{X}_{1} \mathrm{X}_{3}-1.25 \mathrm{X}_{1} \mathrm{X}_{4}+0.91 \mathrm{X}_{2} \mathrm{X}_{3}-0.16 \mathrm{X}_{2} \mathrm{X}_{4}+0.32 \mathrm{X}_{3} \mathrm{X}_{4}
\end{aligned}
$$

\subsubsection{Response Surface Plots}

It is well documented in the literature that initial $\mathrm{pH}$ is an essential operating parameter that strongly affects the EC process performance. The $\mathrm{pH}$ effect on the removal efficiencies of metal ions after EC treatment was validated in the experimental observations. Maximum removal efficiency for $\mathrm{Zn}(99.46 \%), \mathrm{Ni}(98.14 \%)$, and $\mathrm{Cu}(99.96 \%)$ has been observed at $\mathrm{pH} 6$. Figure $4 \mathrm{a}-\mathrm{c}$ demonstrates an increase in the removal efficiency with an increase in $\mathrm{pH}$. This indicates that metal ion elimination decreases in an acidic medium [50]. As reported, in an intensely acidic medium, the protons in the solution get reduced to $\mathrm{H}_{2}$ gas at the cathode, and a sufficient number of hydroxyl ions are not generated. The $\mathrm{pH}$ of the initial solution affects the EC process by changing the solution's physico-chemical properties, such as solubility of metal hydroxides, electric conductivity, and size of colloidal particles of iron (III) complexes, which are most reactive agents for metal ions [51]. A slight reduction in the removal efficiency with the rise in the initial concentration of the metals in solution, as shown in Figure 4, is attributed to the fact that the amount of dissolved iron from the electrode may not have been enough to treat the metal ions present in the wastewater. The higher initial concentration in the feed solution was also reportedly found to significantly affect the EC process [52].

It was observed (Figure $4 \mathrm{~d}-\mathrm{f}$ ) that increasing the constant current substantially reduces metal ions. The constant current emerged as a crucial parameter in improving metal ion removal, which may have contributed to the direct current field, and potential electrolysis, resulting in more release of ferric ions and generating more iron hydroxides, further forming coagulants for metal removal. 


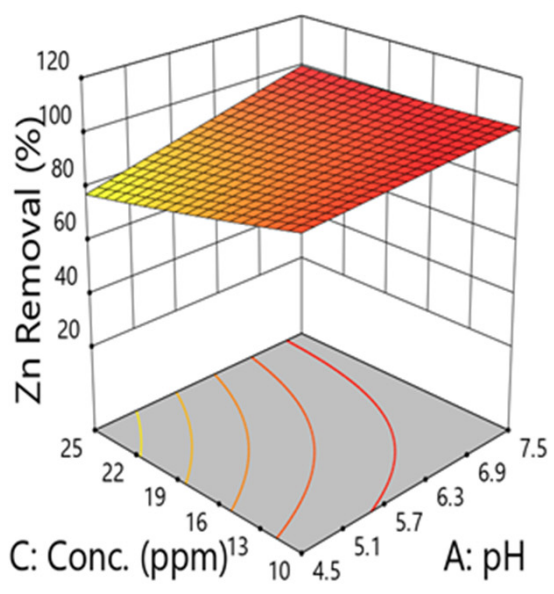

(a)

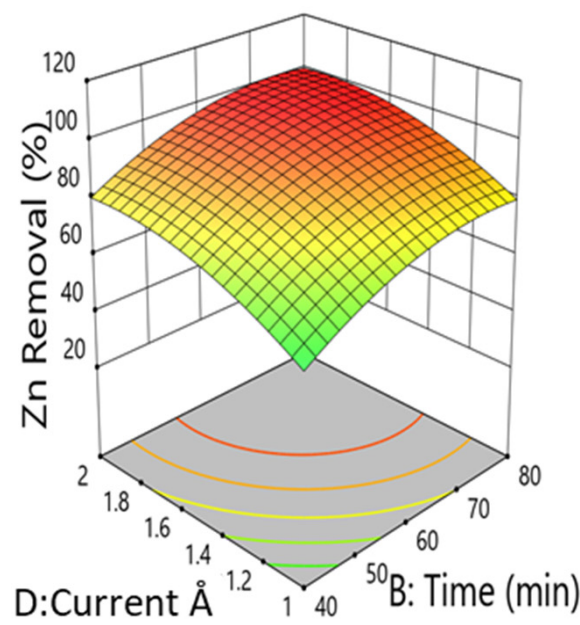

(d)

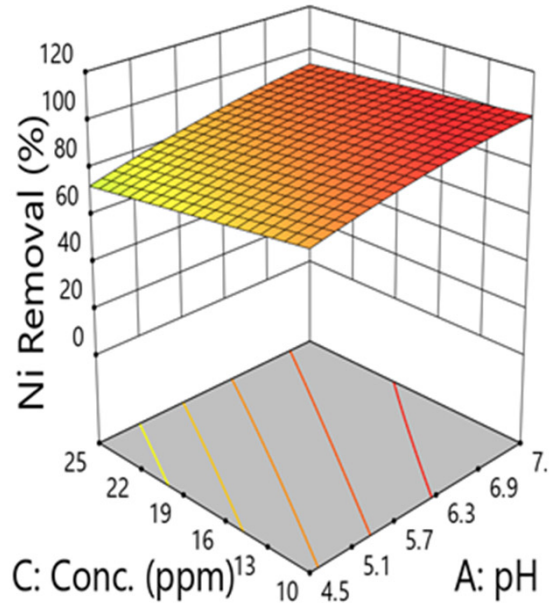

(b)

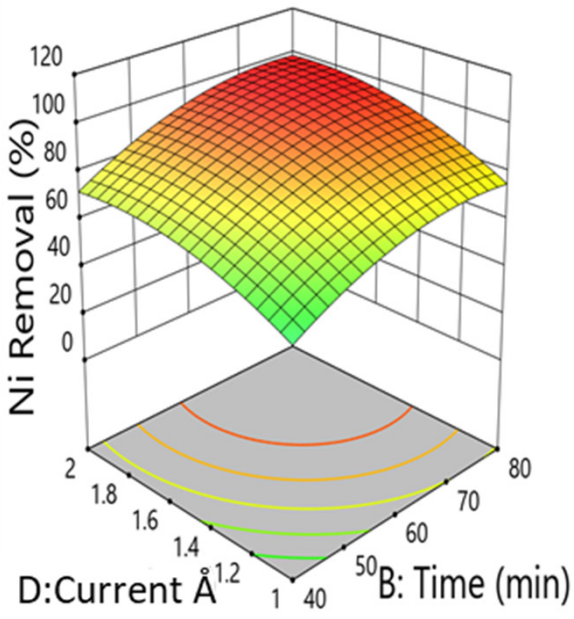

(e)

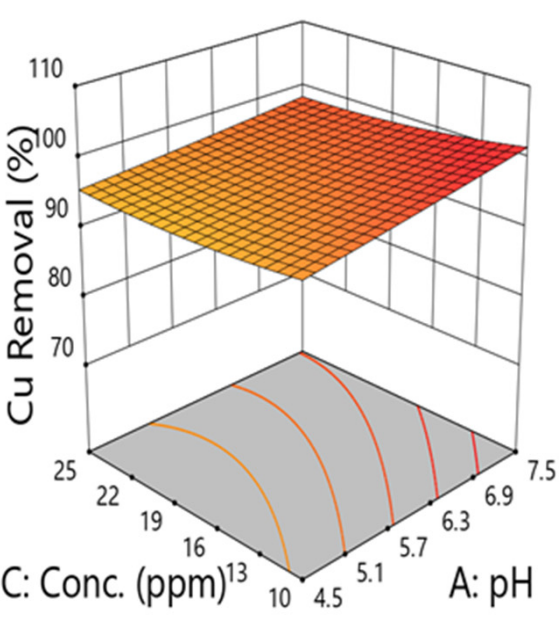

(c)

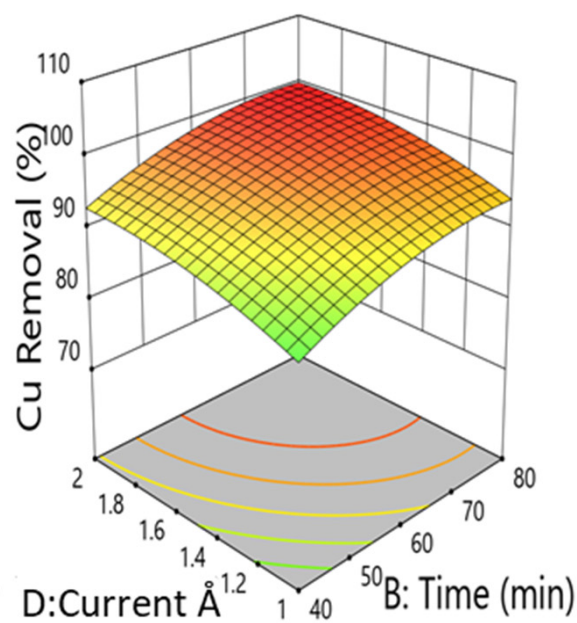

(f)

Figure 4. Electrocoagulation RSM graphs: effects of concentration and $\mathrm{pH}$ on removal\% efficiency of metal ions: (a) Zn ions, (b) Ni ions and (c) Cu ions. Effect of current and reaction time on removal\% efficiency of metal ions: (d) $\mathrm{Zn}$ ions, (e) Ni ions and (f) $\mathrm{Cu}$ ions.

Electrolysis time period plays a vital role in metal ion removal studies along with the constant current, $\mathrm{pH}$ and concentration. The concentration of $\mathrm{Zn}, \mathrm{Ni}$, and $\mathrm{Cu}$ has been observed to decrease with an increase in the electrolysis time. The complete reduction of metal ions was possible at a lower constant current by extending the electrolysis time. It may be stated that higher metal ion concentration consumes the adsorption ability of flocs formed, with fewer flocs being accessible for adsorption. Moreover, removal was limited by the formation rate of flocs of iron hydroxide complexes at the anode surface. It has been shown (Figure 4) that the minimum reduction was observed at lower electrolysis reaction times. The present study highlights that both the current and reaction time play a vital role in the removal efficiency of the EC process. Table 6 reports the results of this study vis-à-vis other studies reported in the literature on metal removal through EC processes. 
Table 6. Overview of metals ion removal efficiency by EC processes described in the literature.

\begin{tabular}{|c|c|c|c|}
\hline Pollutants/Wastewater & E.C. Process & Metal Removal Efficiency & References \\
\hline Synthetic wastewater & SS electrode & $\mathrm{Zn}(99.81 \%), \mathrm{Ni}(99.99 \%)$, and $\mathrm{Cu}(99.98 \%)$ & Current study \\
\hline Synthetic wastewater & Aluminum Electrode & $\begin{array}{l}\mathrm{Ni}^{2+} \text { and } \mathrm{Cu}^{2+} \text { ions } \% \text { removal efficiency } \\
\text { ranged from } 34.56-100 \%\end{array}$ & [53] \\
\hline $\begin{array}{l}\text { Electroplating Industry } \\
\text { wastewater }\end{array}$ & Aluminium plates & $\mathrm{Ni}(99.75 \%)$ & [54] \\
\hline Mine wastewater & Iron Electrodes & $\begin{array}{l}\mathrm{Co}(99 \%) \mathrm{Ni}(97 \%), \mathrm{Zn}(99 \%), \mathrm{Cu}(97 \%), \\
\text { and } \mathrm{Cd}(99 \%) .\end{array}$ & [55] \\
\hline Smelting wastewater & Iron Plates & $\begin{array}{l}\mathrm{Zn}^{2+}, \mathrm{Cd}^{2+}, \text { and } \mathrm{Mn}^{2+} \text { removal efficiency } \\
99.93 \%, 97.15 \% \text {, and } 85.46 \% \text { respectivilty }\end{array}$ & [40] \\
\hline $\begin{array}{l}\text { Synthetic Smelting } \\
\text { Wastewater }\end{array}$ & Fe electrode & $\begin{array}{c}\mathrm{Zn}^{2+}, \mathrm{Cd}^{2+}, \text { and } \mathrm{Mn}^{2+} \text { removal efficiency } \\
99.5 \%, 99.9 \% \text {, and } 55 \% \text { respectively. }\end{array}$ & [56] \\
\hline Metal Plating Wastewater & Iron (carbon steel) plates & $\mathrm{Cu}^{2+}, \mathrm{Cr}^{3+}, \mathrm{Ni}^{2+}$, and $\mathrm{Zn}^{2+}$ over $97 \%$ & [51] \\
\hline Waste Fountain Solution & Aluminium and Iron electrode & $\mathrm{Ni}(>95 \%), \mathrm{Cu}(>95 \%)$, and $\mathrm{Zn}(>80 \%)$ & [57] \\
\hline Metal Plating Effluent & SS Electrode & $\mathrm{Ni}(100 \%)$ and $\mathrm{Zn}(100 \%)$ & [58] \\
\hline
\end{tabular}

\subsubsection{Multi Response Optimization}

For the EC System, the predicted response values of the factors $\left(Y_{1}, Y_{2}\right.$, and $\left.Y_{3}\right)$ were obtained as $101.50 \%, 94.452 \%$, and $98.866 \%$ under optimal operating conditions. Input variables of current and time are the dominant factor in reaction conditions, so the predicted response value shows a higher value. After three experimental runs, the average response values of $Y_{1}, Y_{2}$, and $Y_{3}$ were $99.81 \%, 99.99 \%$, and $99.98 \%$, respectively. All the experimentally attained values are quite close to the predicted response values and show a good correlation (Table 7).

Table 7. EC Optimization of response through RSM.

\begin{tabular}{cccccc}
\hline Optimum Input Variables (Feed Solution) & \multicolumn{2}{c}{ Predicted Responses by RSM } & Experimental Validation & Difference\% \\
\hline $\mathrm{pH}$ & 7 & Zn Removal\% & 101.50 & 99.81 & 1.67 \\
\hline Time & 60 & Ni Removal\% & 94.45 & 99.99 & 5.86 \\
\hline Initial Conc. $(\mathrm{ppm})$ & 24.923 & Cu Removal\% & 98.86 & 99.98 & 1.13 \\
\hline Current $(\AA)$ & 1.912 & - & - & - & - \\
\hline
\end{tabular}

\subsection{Comparison with Chemical Precipitation and Adsorption Processes}

Chemical precipitation is a commonly used treatment process for the removal of heavy metals from industrial wastewater because it is relatively inexpensive and easy to operate. This process involves the precipitation of heavy metals in the form of hydroxide and sulfide. Hydroxide precipitation depends on $\mathrm{pH}$ adjustment (9-11) to basic conditions [58]. The metal ions dissolved in the solution are precipitated into the insoluble solid phase as metal hydroxide through the chemical reaction when quicklime $(\mathrm{CaO})$ is employed as a precipitant. Yet another common treatment process viz., adsorption, on the other hand, is a mass transfer process involving the migration of the metal ions (adsorbate) from the wastewater to a solid surface (adsorbent, commonly $\mathrm{CaCO}_{3}$ ) and binding through physical (weak Van der Waals force) and chemical (strong covalent bond) adsorption mechanisms [59,60]. With an idea to compare the performance of NF and EC processes with the above-stated routine ones, the present study employed concentration, contact time, and dosing amount as operational variables for the conventional chemical treatment process employing $\mathrm{CaO}$ and $\mathrm{CaCO}_{3}$. Twenty experiments were conducted for each process and Table 8 provides details of the experimental design. 
Table 8. Factors and Range of Design for $\mathrm{CaO}$ and $\mathrm{CaCO}_{3}$.

\begin{tabular}{ccccccc}
\hline Factor & Name & Units & Low Actual & High Actual & Low Coded & High Coded \\
\hline $\mathrm{A}$ & Conc. & $\mathrm{ppm}$ & 10.00 & 25.00 & -1.000 & 1.000 \\
\hline $\mathrm{B}$ & Contact Time & Minute & 30.00 & 90.00 & -1.000 & 1.000 \\
\hline $\mathrm{C}$ & Dosing Amount & $\mathrm{g} / \mathrm{L}$ & 4.00 & 8.00 & -1.000 & 1.000 \\
\hline
\end{tabular}

In $\mathrm{CaO}$ precipitation, the removal efficiency of the process was quite high for $\mathrm{Zn}$, $\mathrm{Ni}$, and $\mathrm{Cu}$ ions, as expected and as indicated by the results in Table 9 However, understandably, there are also many demerits in this process. It requires a large amount of chemical precipitant and produces a considerable amount of low-density sludge due to the poor settling properties, duly followed by further dewatering and disposal issues $[60,61]$. Aggregation of metal precipitates also has long term environmental impacts. Treated water also has a very high $\mathrm{pH}(10-12)$, so it cannot be further used in industrial process and requires treatment.

Table 9. Removal\% Efficiency of Conventional $\left(\mathrm{CaO}\right.$ and $\left.\mathrm{CaCO}_{3}\right)$ vs. EC and NF processes.

\begin{tabular}{ccccccc}
\hline S.N. & $\begin{array}{c}\text { Elements } \\
\text { Name }\end{array}$ & Unit & $\begin{array}{c}\mathrm{CaO} \\
\text { (Maximum) }\end{array}$ & $\begin{array}{c}\mathrm{CaCO}_{3} \\
\text { (Maximum) }\end{array}$ & $\begin{array}{c}\text { EC } \\
\text { (Maximum) }\end{array}$ & $\begin{array}{c}\text { NF } \\
\text { (Maximum) }\end{array}$ \\
\hline 1 & Zn Removal & $\%$ & 99.72 & 99.82 & 99.46 & 99.96 \\
\hline 2 & Ni Removal & $\%$ & 99.96 & 43.46 & 98.14 & 99.63 \\
\hline 3 & Cu Removal & $\%$ & 99.99 & 99.99 & 99.96 & 99.99 \\
\hline
\end{tabular}

Regarding the $\mathrm{CaCO}_{3}$ adsorption process, the results presented in Table 9 indicate that the removal of $\mathrm{Ni}$ ions is not as efficient as for $\mathrm{Cu}$ and $\mathrm{Zn}$ ions. In the adsorption process, generated sludge needs to be separated from the solution and requires regeneration or labelling as a hazardous waste due to the strong possibility of leaching out of metals ions in the environment, while needing post-treatment sludge management. Van der Waal forces are very weak to strong for different adsorbents, due to which the process is unable to deliver promising results [62-64].

NF process lies between ultrafiltration (UF) and reverse osmosis (RO). Designed to separate contaminants smaller than $10 \mathrm{~nm}$, it emerges as one of the exemplary processes for eliminating dissolved metals ions from wastewater. The leading gains of this process are higher removal efficiency, reliability and easy operation, lesser space requirement, and relatively lower energy requirement $[60,63,65]$. Table 9 shows an outstanding rejection rate for metals ions from this study.

The EC process is also widely recognized as an effective treatment method for eliminating heavy metal ions from industrial wastewater. It does not require any additional chemicals because the electron is a crucial reagent in the process. EC is considered a rapid and well-controlled technique, provides good reduction yield, produces less sludge, has the potential of metal recovery, requires less labor, can save significant energy, and is ecofriendly $[57,59]$. Table 9 shows an excellent metal ion reduction in the present experimental work.

\section{Conclusions}

The present study examines the removal efficiency of heavy metals $(\mathrm{Cu}, \mathrm{Ni}$, and $\mathrm{Zn})$ in a mixed aqueous solution in a batch mode through a nanofiltration (NF) membrane and an electrocoagulation (EC) process and compares it with conventional chemical treatment processes. Solution $\mathrm{pH}$ is seen to significantly affect the removal efficiency in both the $\mathrm{NF}$ and EC processes. The highest permeate flux of $59.34 \mathrm{~L} / \mathrm{m}^{2} \cdot \mathrm{h}$ was observed at the experimental condition of $\mathrm{pH} 9.5$, pressure $25 \mathrm{Bar}$, concentration $25 \mathrm{ppm}$ and temperature $35{ }^{\circ} \mathrm{C}$ in NF process. The rejection rate of $\mathrm{Zn}, \mathrm{Ni}$ and $\mathrm{Cu}$ was demonstrated as $95.32 \%$, $94.98 \%$ and $96.93 \%$, respectively. A marked synergistic effect of temperature and pressure has been observed, which increased the flux to a high value. The EC process has shown 
a maximum removal of $\mathrm{Zn}(99.46 \%), \mathrm{Ni}(98.14 \%)$, and $\mathrm{Cu}(99.87 \%)$ at the operational conditions viz., pH 6, time 60 (min), concentration 2.5 ppm, and current $1.5 \AA$. The results for the EC process indicated that a lower concentration and approximately neutral $\mathrm{pH}$ helped the system to reach its full potential. Overall, both NF and EC processes have shown excellent removal for all the studied metal ions and the outcome of the experiments described above projects them as promising solutions in comparison to conventional chemical treatment approaches.

Supplementary Materials: The following supporting information can be downloaded at: https: / / www.mdpi.com/article/10.3390/app12010280/s1, Table S1: Experimental design and responses of the NF process; Table S2: Experimental design and responses of the EC process.

Author Contributions: Conceptualization, J.K. and H.J.; methodology, J.K. and H.J.; software, J.K.; formal analysis, J.K. and S.K.M.; investigation, J.K.; resources, H.J. and S.K.M.; writing-original draft preparation, J.K.; writing, review and editing, H.J. and S.K.M. All authors have read and agreed to the published version of the manuscript.

Funding: This research received no external funding.

Data Availability Statement: All relevant data are within the manuscript and available from the corresponding author on request.

Acknowledgments: This work has been carried out with the Junior/Senior Research Fellowship of the University Grant Commission (UGC), New Delhi, India, under the Ph.D. programme. Authors are highly thankful to the Indian Institute of Technology Roorkee, Roorkee for providing the necessary support and encouragement for bringing out this publication.

Conflicts of Interest: The authors declare no conflict of interest or state.

\section{References}

1. Tchounwou, P.B.; Yedjou, C.G.; Patlolla, A.K.; Sutton, D.J. Molecular, clinical and environmental toxicicology Volume 3: Environmental Toxicology. Mol. Clin. Environ. Toxicol. 2012, 101, 133-164. [CrossRef]

2. Vareda, J.P.; Valente, A.J.M.; Durães, L. Assessment of heavy metal pollution from anthropogenic activities and remediation strategies: A review. J. Environ. Manag. 2019, 246, 101-118. [CrossRef] [PubMed]

3. Hussain, J.; Husain, I.; Arif, M.; Gupta, N. Studies on heavy metal contamination in Godavari river basin. Appl. Water Sci. 2017, 7, 4539-4548. [CrossRef]

4. Malyan, S.K.; Singh, R.; Rawat, M.; Kumar, M.; Pugazhendhi, A.; Kumar, A.; Kumar, V.; Kumar, S.S. Biocatalysis and Agricultural Biotechnology An overview of carcinogenic pollutants in groundwater of India. Biocatal. Agric. Biotechnol. 2019, $21,101288$. [CrossRef]

5. Kumar, A.; Malyan, S.K.; Kumar, S.S.; Dutt, D.; Kumar, V. Biocatalysis and Agricultural Biotechnology An assessment of trace element contamination in groundwater aquifers of. Biocatal. Agric. Biotechnol. 2019, 20, 101213. [CrossRef]

6. Kumar, A.; Jigyasu, D.K.; Subrahmanyam, G.; Mondal, R.; Shabnam, A.A.; Cabral-Pinto, M.M.S.; Malyan, S.K.; Chaturvedi, A.K.; Gupta, D.K.; Fagodiya, R.K.; et al. Nickel in terrestrial biota: Comprehensive review on contamination, toxicity, tolerance and its remediation approaches. Chemosphere 2021, 275, 129996. [CrossRef]

7. Kumar, A.; Pinto, M.C.; Candeias, C.; Dinis, P.A. Baseline maps of potentially toxic elements in the soils of Garhwal Himalayas, India: Assessment of their eco-environmental and human health risks. Land Degrad. Dev. 2021, 32, 3856-3869. [CrossRef]

8. Maher, A.; Sadeghi, M.; Moheb, A. Heavy metal elimination from drinking water using nanofiltration membrane technology and process optimization using response surface methodology. Desalination 2014, 352, 166-173. [CrossRef]

9. Tonhá, M.S.; Garnier, J.; Araújo, D.F.; Cunha, B.C.A.; Machado, W.; Dantas, E.; Araújo, R.; Kutter, V.T.; Bonnet, M.P.; Seyler, P. Behavior of metallurgical zinc contamination in coastal environments: A survey of $\mathrm{Zn}$ from electroplating wastes and partitioning in sediments. Sci. Total Environ. 2020, 743, 140610. [CrossRef] [PubMed]

10. Rodrigues, S.K.; Machado, W.; Guerra, J.V.; Geraldes, M.; Morales, S.; Vinzón, S.B. Changes in Cd and Zn distribution in sediments after closure of an electroplating industry, Sepetiba bay, Brazil. Mar. Pollut. Bull. 2020, 161, 111758. [CrossRef] [PubMed]

11. Nriagu, J. Zinc Toxicity in Humans. Encycl. Environ. Health 2011, 801-807. [CrossRef]

12. Qu, L.; Huang, H.; Xia, F.; Liu, Y.; Dahlgren, R.A.; Zhang, M.; Mei, K. Risk analysis of heavy metal concentration in surface waters across the rural-urban interface of the Wen-Rui Tang River, China. Environ. Pollut. 2018, 237, 639-649. [CrossRef] [PubMed]

13. Kumar, A.; Subrahmanyam, G.; Mondal, R.; Cabral-pinto, M.M.S.; Shabnam, A.A.; Jigyasu, D.K.; Malyan, S.K.; Kishor, R.; Khan, S.A.; Kumar, A.; et al. Chemosphere Bio-remediation approaches for alleviation of cadmium contamination in natural resources. Chemosphere 2021, 268, 128855. [CrossRef] [PubMed] 
14. Tatiana, A.; Manceau, A.; Spadini, L.; Panfili, F.; Marcus, M.A.; Jacquet, T. Speciation and solubility of heavy metals in contaminated soil using X-ray microfluorescence, EXAFS spectroscopy, chemical extraction, and thermodynamic modeling. Geochim. Cosmochim. Acta 2006, 70, 2163-2190. [CrossRef]

15. Li, Y.; Tsend, N.; Li, T.K.; Liu, H.; Yang, R.; Gai, X.; Wang, H.; Shan, S. Microwave assisted hydrothermal preparation of rice straw hydrochars for adsorption of organics and heavy metals. Bioresour. Technol. 2019, 273, 136-143. [CrossRef] [PubMed]

16. Sadeek, A.; Negm, N.A.; Hefni, H.H.H.; Wahab, M.M.A. Metal adsorption by agricultural biosorbents: Adsorption isotherm, kinetic and biosorbents chemical structures. Int. J. Biol. Macromol. 2015, 81, 400-409. [CrossRef]

17. WHO. 2017 World Health Statistics 2017: Monitoring Health for the SDGs, Sustainable Development Goals; World Health Organization: Geneva, Switzerland, 2017.

18. UN-Water. World Water Assessment Programme (Nations Unies), the United Nations World Water Development Report 2018; United Nations Educational, Scientific and Cultural Organization: New York, NY, USA, 2018. Available online: https://www.unwater. org/publications /world-water-development-report-2018/ (accessed on 14 October 2021).

19. Pandit, A.B.; Kumar, J.K. Clean Water for Developing Countries. Annu. Rev. Chem. Biomol. Eng. 2015, 6, 217-246. [CrossRef] [PubMed]

20. Price, J.R.; Ledford, S.H.; Ryan, M.O.; Toran, L.; Sales, C.M. Science of the Total Environment Wastewater treatment plant effluent introduces recoverable shifts in microbial community composition in receiving streams. Sci. Total Environ. 2018, 613-614, 1104-1116. [CrossRef] [PubMed]

21. Kumar, S.S.; Kadier, A.; Malyan, S.K.; Ahmad, A. Phytoremediation and Rhizoremediation: Uptake, Mobilization and Sequestration of Heavy Metals by Plants. In Plant-Microbe Interactions in Agro-Ecological Perspectives; Singh, D., Singh, H., Prabha, R., Eds.; Springer: Singapore, 2017. [CrossRef]

22. Malyan, S.K.; Yadav, S.; Sonkar, V.; Goyal, V.C.; Singh, O.; Singh, R. Mechanistic understanding of the pollutant removal and transformation processes in the constructed wetland system. Water Environ. Res. 2021, 93, 1882-1909. [CrossRef] [PubMed]

23. Wu, J.; Huang, R.; Zhou, Q.; Lu, H.; Li, F.; Wu, K.; Li, Z. Science of the Total Environment Magnetic biochar reduces phosphorus uptake by Phragmites australis during heavy metal remediation. Sci. Total Environ. 2021, 758, 143643. [CrossRef] [PubMed]

24. Malyan, S.K.; Kumar, S.S.; Fagodiya, R.K.; Ghosh, P.; Kumar, A.; Singh, R.; Singh, L. Biochar for environmental sustainability in the energy-water-agroecosystem nexus. Renew. Sustain. Energy Rev. 2021, 149, 111379. [CrossRef]

25. Kumar, D.; Sharma, C. Remediation of Pulp and Paper Industry Effluent Using Electrocoagulation Process. J. Water Resour. Prot. 2019, 11, 296-310. [CrossRef]

26. Kurniawan, T.A.; Chan, G.Y.S.; Lo, W.H.; Babel, S. Physico-chemical treatment techniques for wastewater laden with heavy metals. Chem. Eng. J. 2006, 118, 83-98. [CrossRef]

27. Singh, V.; Ram, C. Physico-Chemical Characterization of Electroplating Industrial Effluents of Chandigarh and Haryana Region J. Civ. Environ. Eng. 2016, 6, 4. [CrossRef]

28. Sivakumar, D.; Nouri, J.; Modhini, T.M.; Deepalakshmi, K. Nickel removal from electroplating industry wastewater: A bamboo activated carbon. Glob. J. Environ. Sci. Manag. 2018, 4, 325-338. [CrossRef]

29. Dasgupta, J.; Mondal, D.; Chakraborty, S.; Sikder, J.; Curcio, S.; Arafat, H.A. Nano filtration based water reclamation from tannery effluent following coagulation pretreatment. Ecotoxicol. Environ. Saf. 2015, 121, 22-30. [CrossRef] [PubMed]

30. Almeida, M.; Erthal, R.; Padua, E.; Silveira, L.; Am, L. Response surface methodology (RSM) as a tool for optimization in analytical chemistry. Talanta 2008, 76, 965-977. [CrossRef]

31. Srivastava, A.; Aghilesh, K.; Nair, A.; Ram, S.; Agarwal, S.; Ali, J.; Singh, R.; Chandra, M. Response surface methodology and artificial neural network modelling for the performance evaluation of pilot-scale hybrid nanofiltration (NF) \& reverse osmosis (RO) membrane system for the treatment of brackish ground water. J. Environ. Manag. 2021, 278, 111497.

32. Sinha, A.; Biswas, P.; Sarkar, S.; Bora, U.; Purkait, M.K. Separation of chloride and sulphate ions from nano fi ltration rejected wastewater of steel industry. J. Water Process Eng. 2020, 33, 101108. [CrossRef]

33. Madaeni, S.S.; Arast, N.; Rahimpour, F.; Arast, Y. Fabrication optimization of acrylonitrile butadiene styrene (ABS)/polyvinylpyrrolidone (PVP) nano fi ltration membrane using response surface methodology. Desalination 2011, 280, 305-312. [CrossRef]

34. Patidar, R.; Srivastava, V.C. Chemosphere Mechanistic insight into ultrasound-induced enhancement of electrochemical oxidation of o fl oxacin: Multi-response optimization and cost analysis. Chemosphere 2020, 257, 127121. [CrossRef] [PubMed]

35. Roy, Y.; Warsinger, D.M.; Lienhard, J.H. Effect of temperature on ion transport in nanofiltration membranes: Diffusion, convection and electromigration. Desalination 2017, 420, 241-257. [CrossRef]

36. Figoli, A.; Cassano, A.; Criscuoli, A.; Mozumder, M.S.I.; Uddin, M.T.; Islam, M.A.; Drioli, E. Influence of operating parameters on the arsenic removal by nanofiltration. Water Res. 2010, 44, 97-104. [CrossRef] [PubMed]

37. Al-Rashdi, B.A.M.; Johnson, D.J.; Hilal, N. Removal of heavy metal ions by nanofiltration. Desalination 2013, 315, 2-17. [CrossRef]

38. Gherasim, C.V.; Mikulášek, P. Influence of operating variables on the removal of heavy metal ions from aqueous solutions by nanofiltration. Desalination 2014, 343, 67-74. [CrossRef]

39. Zhou, R.; Liu, F.; Wei, N.; Yang, C.; Yang, J.; Wu, Y.; Li, Y. Comparison of Cr (VI) removal by direct and pulse current electrocoagulation: Implications for energy consumption optimization, sludge reduction and floc magnetism. J. Water Process Eng. 2020, 37, 101387. [CrossRef]

40. Xu, L.; Xu, X.; Cao, G.; Liu, S.; Duan, Z.; Song, S.; Song, M.; Zhang, M. Optimization and assessment of Fe e electrocoagulation for the removal of potentially toxic metals from real smelting wastewater. J. Environ. Manag. 2018, 218, 129-138. [CrossRef] [PubMed] 
41. Pino, L.; Vargas, C.; Schwarz, A.; Borquez, R. Influence of operating conditions on the removal of metals and sulfate from copper acid mine drainage by nanofiltration. Chem. Eng. J. 2018, 345, 114-125. [CrossRef]

42. Tsuru, T.; Izumi, S.; Yoshioka, T.; Asaeda, M. Temperature effect on transport performance by inorganic nanofiltration membranes. AIChE J. 2000, 46, 565-574. [CrossRef]

43. Micari, M.; Diamantidou, D.; Heijman, B.; Moser, M.; Haidari, A.; Spanjers, H.; Bertsch, V. Experimental and theoretical characterization of commercial nanofiltration membranes for the treatment of ion exchange spent regenerant. J. Memb. Sci. 2020, 606, 118117. [CrossRef]

44. Peydayesh, M.; Mohammadi, T.; Nikouzad, S.K. A positively charged composite loose nanofiltration membrane for water purification from heavy metals. J. Memb. Sci. 2020, 611, 118205. [CrossRef]

45. Hamid, M.F.; Abdullah, N.; Yusof, N.; Ismail, N.M.; Ismail, A.F.; Salleh, W.N.W.; Jaafar, J.; Aziz, F.; Lau, W.J. Effects of surface charge of thin-film composite membrane on copper (II) ion removal by using nanofiltration and forward osmosis process. J. Water Process Eng. 2020, 33, 101032. [CrossRef]

46. Wang, J.; Yu, W.; Graham, N.J.D.; Jiang, L. Evaluation of a novel polyamide-polyethylenimine nanofiltration membrane for wastewater treatment: Removal of $\mathrm{Cu}^{2+}$ ions. Chem. Eng. J. 2020, 392, 123769. [CrossRef]

47. Roy, S.; Majumdar, S.; Sahoo, G.C.; Bhowmick, S.; Kundu, A.K.; Mondal, P. Removal of As(V), Cr(VI) and Cu(II) using novel amine functionalized composite nanofiltration membranes fabricated on ceramic tubular substrate. J. Hazard. Mater. 2020, 399, 122841. [CrossRef] [PubMed]

48. Hosseini, S.S.; Nazif, A.; Shahmirzadi, M.A.A.; Ortiz, I. Fabrication, tuning and optimization of poly (acrilonitryle) nanofiltration membranes for effective nickel and chromium removal from electroplating wastewater. Sep. Purif. Technol. 2017, 187, 46-59. [CrossRef]

49. Chaudhari, L.B.; Murthy, Z.V.P. Separation of Cd and Ni from multicomponent aqueous solutions by nanofiltration and characterization of membrane using IT model. J. Hazard. Mater. 2010, 180, 309-315. [CrossRef] [PubMed]

50. Murthy, Z.V.P.; Chaudhari, L.B. Separation of binary heavy metals from aqueous solutions by nanofiltration and characterization of the membrane using Spiegler-Kedem model. Chem. Eng. J. 2009, 150, 181-187. [CrossRef]

51. Al-shannag, M.; Al-qodah, Z.; Bani-melhem, K.; Rasool, M. Heavy metal ions removal from metal plating wastewater using electrocoagulation: Kinetic study and process performance. Chem. Eng. J. 2015, 260, 749-756. [CrossRef]

52. Mollah, M.Y.A.; Schennach, R.; Parga, J.R.; Cocke, D.L. Electrocoagulation (EC)—Science and applications. J. Hazard. Mater. 2001, 84, 29-41. [CrossRef]

53. El-Ashtoukhy, E.S.Z.; Amin, N.K.; Fouad, Y.O.; Hamad, H.A. Intensification of a new electrocoagulation system characterized by minimum energy consumption and maximum removal efficiency of heavy metals from simulated wastewater. Chem. Eng. Process.-Process Intensif. 2020, 154, 108026. [CrossRef]

54. Sarwanto, S.; Nugroho, R.; Handayani, M.; Pratama, M.A. Heliyon Optimization and reaction kinetics on the removal of Nickel and COD from wastewater from electroplating industry using Electrocoagulation and Advanced Oxidation Processes. Heliyon 2020, 6, e03319. [CrossRef]

55. Mamelkina, M.A.; Vasilyev, F.; Tuunila, R.; Sillanpää, M.; Häkkinen, A. Investigation of the parameters affecting the treatment of mining waters by electrocoagulation. J. Water Process Eng. 2019, 32, 100929. [CrossRef]

56. Xu, L.; Cao, G.; Xu, X.; Liu, S.; Duan, Z.; He, C.; Wang, Y.; Huang, Q. Simultaneous removal of cadmium, zinc and manganese using electrocoagulation: Influence of operating parameters and electrolyte nature. J. Environ. Manag. 2017, 204, 394-403. [CrossRef]

57. Prica, M.; Adamovic, S.; Dalmacija, B.; Rajic, L. The electrocoagulation/flotation study: The removal of heavy metals from the waste fountain. Process Saf. Environ. Prot. 2014, 94, 262-273. [CrossRef]

58. Arslan, T.; Arslan-alaton, I.; Tünay, O. Complexing agent and heavy metal removals from metal plating effluent by electrocoagulation with stainless steel electrodes. J. Hazard. Mater. 2009, 165, 838-845. [CrossRef]

59. Malik, L.A.; Bashir, A.; Qureashi, A.; Pandith, A.H. Detection and removal of heavy metal ions: A review. Environ. Chem. Lett. 2019, 17, 1495-1521. [CrossRef]

60. Bolisetty, S.; Peydayesh, M.; Mezzenga, R. Sustainable technologies for water purification from heavy metals: Review and analysis. Chem. Soc. Rev. 2019, 48, 463-487. [CrossRef]

61. Fu, F.; Wang, Q. Removal of heavy metal ions from wastewaters: A review. J. Environ. Manag. 2011, 92, 407-418. [CrossRef]

62. Vunain, E.; Mishra, A.K.; Mamba, B.B. Dendrimers, mesoporous silicas and chitosan-based nanosorbents for the removal of heavy-metal ions: A review. Int. J. Biol. Macromol. 2016, 86, 570-586. [CrossRef] [PubMed]

63. Abdullah, N.; Yusof, N.; Lau, W.J.; Jaafar, J.; Ismail, A.F. Recent trends of heavy metal removal from water/wastewater by membrane technologies. J. Ind. Eng. Chem. 2019, 76, 17-38. [CrossRef]

64. Zhao, M.; Xu, Y.; Zhang, C.; Rong, H.; Zeng, G. New trends in removing heavy metals from wastewater. Appl. Microbiol. Biotechnol. 2016, 100, 6509-6518. [CrossRef]

65. Vardhan, K.H.; Kumar, P.S.; Panda, R.C. A review on heavy metal pollution, toxicity and remedial measures: Current trends and future perspectives. J. Mol. Liq. 2019, 290, 111197. [CrossRef] 